\title{
From thyroid cartilage to thyroid gland
}

\author{
K. Laios ${ }^{1}$, E. Lagiou², V. Konofaou³, M. Piagkou4, M. Karamanou ${ }^{5}$ \\ 'Medical School, National and Kapodistrian University of Athens, Greece \\ ${ }^{2}$ Medical School, University of Patras, Greece \\ ${ }^{3}$ Neurosurgical Department, Children Hospital 'P. \& A. Kyriakou', Athens, Greece \\ ${ }^{4}$ Department of Anatomy, Medical School, National and Kapodistrian University of Athens, Greece \\ ${ }^{5}$ History of Medicine Department, University of Crete, Greece
}

[Received: 13 May 2018; Accepted: 18 June 2018]

The ancient Greek physicians skipped the description of thyroid gland probably due to their difficultly to understand the anatomy and the existence of this organ. Although the ancient physicians had described the disease bronchocele (Greek:

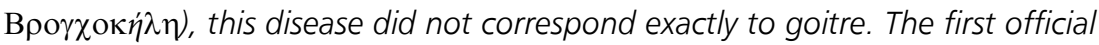
description of this gland was made by Andreas Vesalius (1514-1564). Thomas Wharton (1614-1673) in his work Adenographia was the one who coined the term 'Glandulae thyreoidea'. (Folia Morphol 2019; 78, 1: 171-173)

Key words: botium, thyroid foramen, Galen, Thomas Wharton

\section{INTRODUCTION}

From the Greek-English Lexicon by Henry George Liddell and Robert Scott we can learn that in ancient Greek literature the noun Thyra (Greek: $\Theta v ́ \rho \alpha$ ) meant the door. Also we are informed that from this noun derived as well the noun Thyreos (Greek: @upcós) meant either 'a stone put against a door to keep it shut' or 'a large oblong shield (shaped like a door)'. From the noun Thyreos derived the adjective thyreoid (Greek: $\theta 0 \rho \varepsilon o \varepsilon ı \delta \eta^{\prime} \varsigma$ ). This adjective was used in ancient Greek medical literature in order to describe the thyroid cartilage [10].

\section{MATERIALS AND METHODS}

The description of thyroid cartilage by the term

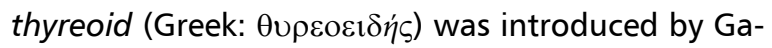
len ( $1^{\text {st }}$ to $2^{\text {nd }}$ century $A D$ ) who many times used this term in his studies such as: Galenus Med. De usu partium 3.552.1; 3.552.14; 3.555.19; 3.557.1; 3.557 .8 ; 3.557.10; 3.559.6; 3.559.13; 3.561.7; $3.568 .3 ; 3.568 .7 ; 3.592 .15 ; 4.279 .10 ; 4.279 .14$; $4.280 .3 ; 4.280 .9 ; 4.280 .18$ [5] and Galenus Med. De musculorum dissectione ad tirones 18b.949.15; 18b.950.6; 18b.950.10; 18b.951.5 [9].

\section{RESULTS}

Galen's terminology was accepted and repeated by the later physicians. The Byzantine physician Oribasius of Pergamon ( $4^{\text {th }}$ century AD) used also a lot this term but in addition he for the first time explained its use pointing that this cartilage received that name due to its resemblance to a shield (Oribasius Med. Collectiones medicae 24.9.4.1-2) [11]. The same term was also used by the other Byzantine physician Theophilus Protospatharius ( $9^{\text {th }}$ to $10^{\text {th }}$ century AD) in his anatomical study (Theophilus Protospatharius De corporis humani fabrica libri quinque 3.14.4; 3.15.2) [3]. In this point we should bear in mind that in Galen's medical text we found for the first time the adjective thyroeides (Greek: $\theta u p o \varepsilon ı \delta \varepsilon \xi)$ which derived from the Greek noun Thyra, that is the Greek word for the door, in order to describe the thyroid foramen in the pelvis (Galenus Med. De anatomicis administrationibus libri ix 2.414.1-3) [7]. Galen did not introduce this term because it was introduced earlier as he had noticed.

\section{DISCUSSION}

Until now we did not notice the description of thyroid gland. The ancient physicians skipped its de- 


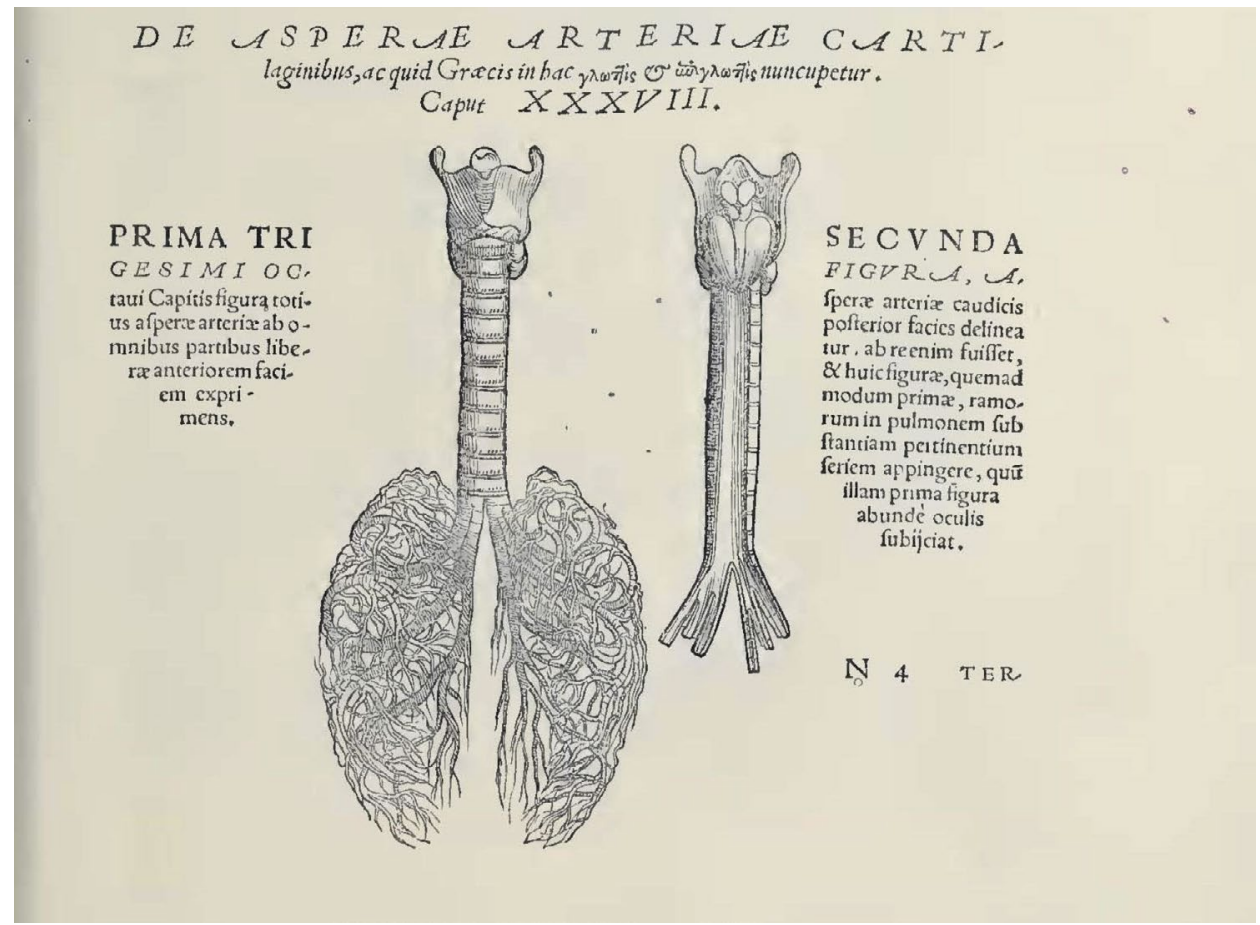

Figure 1. The first anatomical sketch of thyroid gland in Andreas Vesalius book of anatomy. Figure 1 derives from the book: Vesalius $A, 1543$ Andreae Vesalii Bruxellensis De humani corporis fabrica libri septem. Basileæ: Ex officina loannis Oporini.

scription probably due to their difficultly to understand the anatomy and the existence of this organ. Although the ancient physicians had described the

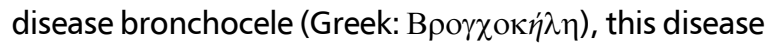
did not correspond exactly to goitre. As bronchocele was considered every growth found in the throat. Mainly it was considered as an aneurysm of the trachea, but also various types of this growth which could be fleshy, watery, fatty, hard and cancerous point many other pathologies found in this anatomical area such as cysts, nodes, aneurisms or cancers, while goitre could not be excluded but not specified, as we learn by Pseudo-Galen ( $1^{\text {st }}$ to $2^{\text {nd }}$ century AD) (Pseudo-Galen Definitiones medicae 19.443.17-18) [8] and Paul of Aegina ( $7^{\text {th }}$ century AD) (Paulus Med. Epitomae medicae libri septem 6.38.1.1-9) [4].

The first official description of this gland was made by Andreas Vesalius (1514-1564) in his fundamental work on anatomy entitled, De humani corporis fabrica libri septem (On the Fabric of the Human Body). There, for the first time, we come across the anatomical observation of this organ, which was named as Glandulae laryngi appositae (gland attached to the larynx). In this work we also found its first anatomical sketch (Fig. 1) [12]. In addition, Gaspard Bauhin (1560-1624) in his work Theatrum anatomicum, used the term Glandulae laryngi abstantas (gland distant to the larynx) [2] and Thomas Bartolin (1616-1680) in his work Anatomia, the term Glandulae laryngi adjacentes (gland near to the larynx) [1]. Thomas Wharton (1614-1673) in his work Adenographia was the one who coined the term Glandulae thyreoidea [13]. Nevertheless, we should bear in mind that another term was also used to describe thyroid gland. This was the term Botium or Bocium. This was the Latinised Arabic term Bothor, which was used mainly to describe not only thyroid gland but also goitre, even if this was used as well to describe tumours and abscesses or growths in general [6].

The term Thyreoid gland was gradually substituted by the term Thyroid gland, omitting the vowel-e-in order to be easier for the English-spoken scholars to describe this gland but it should be underlined that this term should not be confused with the analogous term used to describe the thyroid foramen because they have different context.

\section{CONCLUSIONS}

In conclusion, from this historical review of this special medical terminology we can understand how the ancient Greek physicians coined the anatomical terminology, their influence to the later physicians who adapted their medical terms, how the modern scientific approach to anatomy which began with 
Andreas Vesalius, revised the ancient doctrines, and finally how ancient anatomical terminology was reintroduced in modern medicine in current context. Therefore, the history of an anatomical term is an excellent opportunity for us to understand the evolution of modern medicine.

\section{REFERENCES}

1. Bartolin T. Anatomia, ex Caspari Bartholini parentis Institutionibus: omniumque recentiorum \& propriis observationibus tertiùm ad sanguinis circulationem reformata. Cum iconibus novis accuratissimis. Lugd. Batav, Apud Franciscum Hackium 1655.

2. Bauhin C. Theatrum anatomicum Caspari Bauhini Basillen. Archiatri infinitis locis auctum, ad morbos accommodatum $\& a b$ erroribus $a b$ authore repurgatum: observationibus \& figuris aliquot novis æneis illustratum. Francofurti atMoenum, Typis Matthaei Beckeri 1605.

3. Greenhill GA. De corporis humani fabrica libri quinque, Theophili Protospatharii de corporis humani fabrica libri v. Oxford University Press, Oxford 1842.
4. Heiberg JL. Paulus Aegineta, Epitomae medicae libri septem. Vol.2. Teubner, Leipzig 1924.

5. Helmreich G. Galeni de usu partium libri xvii. Teubner, Leipzig 1909.

6. Hyrtl J. Onomatologia Anatomica. Geschichte und Kritik der anatomischen Sprache der Gegenwart. Wilhelm Braumüller. K.K. Hof- und Universitätsbuchhändler, Wien 1880.

7. Kühn CG. Claudii Galeni opera omnia, De anatomicis administrationibus libri ix. Vol.2. Knobloch, Leipzig 1821.

8. Kühn CG. Claudii Galeni opera omnia, Definitiones medicae. Vol.19. Knobloch, Leipzig 1830.

9. Kühn CG. Claudii Galeni opera omnia, De musculorum dissectione ad tirones. Vol. 18.2. Knobloch, Leipzig 1830.

10. Liddell HG, Scott RA. Greek-English Lexicon. revised and augmented throughout by Sir Henry Stuart Jones with the assistance of Roderick McKenzie. Clarendon Press, Oxford 1940.

11. Raeder J. Oribasii collectionum medicarum reliquiae. Vol.4. Teubner, Leipzig 1933.

12. Vesalius A. Andreae Vesalii Bruxellensis De humani corporis fabrica libri septem. Ex officina loannis Oporini, Basileæ 1543.

13. Wharton T. Adenographia: sive glandularum totius corporis descriptio. Sumptibus Joannis Ravesteinii, Amstelaedami 1659. 